\title{
SS-03 'The End of the Fossil Fuel Age'? Discourse Politics and Climate Change Political Economy
}

DOI:

10.1080/13563467.2020.1810218

\section{Document Version}

Accepted author manuscript

Link to publication record in Manchester Research Explorer

\section{Citation for published version (APA):}

Paterson, M. (2021). SS-03 'The End of the Fossil Fuel Age'? Discourse Politics and Climate Change Political Economy: Discourse politics and climate change political economy. New Political Economy, 26(6), 923-936. https://doi.org/10.1080/13563467.2020.1810218

\section{Published in:}

New Political Economy

\section{Citing this paper}

Please note that where the full-text provided on Manchester Research Explorer is the Author Accepted Manuscript or Proof version this may differ from the final Published version. If citing, it is advised that you check and use the publisher's definitive version.

\section{General rights}

Copyright and moral rights for the publications made accessible in the Research Explorer are retained by the authors and/or other copyright owners and it is a condition of accessing publications that users recognise and abide by the legal requirements associated with these rights.

\section{Takedown policy}

If you believe that this document breaches copyright please refer to the University of Manchester's Takedown Procedures [http://man.ac.uk/04Y6Bo] or contact uml.scholarlycommunications@manchester.ac.uk providing relevant details, so we can investigate your claim.

\section{OPEN ACCESS}




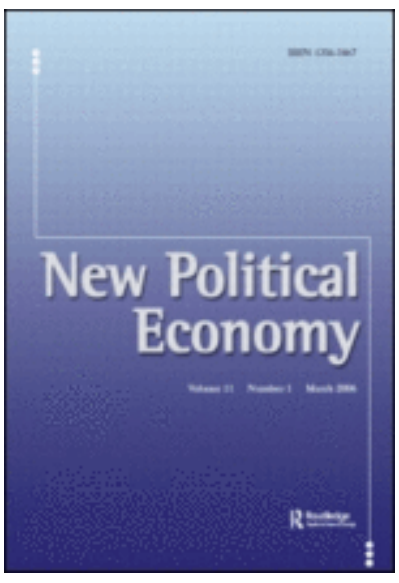

'The end of the fossil fuel age'? Discourse politics and climate change political economy

\begin{tabular}{|r|l|}
\hline Journal: & New Political Economy \\
\hline Manuscript ID & Draft \\
\hline Manuscript Type: & Original Article \\
\hline \multicolumn{2}{l}{} \\
\hline
\end{tabular}

\section{SCHOLARONE ${ }^{\text {TM }}$ Manuscripts}




\title{
SS-03 'The end of the fossil fuel age'? Discourse politics and climate change political economy
}

Paper for New Political Economy special section 'the politics of green transformation'

\begin{abstract}
This paper explores the implications of the reframing of climate change as a question of the 'end of the fossil fuel age'. This was a common interpretation of the logic of the Paris Agreement in the UNFCCC in December 2015, the implications of the IPCC's fifth assessment report, and in the framing of climate change by the fossil fuel divestment movement. The paper argues that this signifies an important shift in the framing of climate change, away from ones such as 'emissions reduction' or 'decarbonisation', towards more transformational understandings of climate change. It aims to contribute to attempts to repoliticise climate change by focusing on how this frame helps us re-emphasise the political conflicts inherent to climate change politics, ignored by more technocratic visions of 'economic efficiency' or 'transition management'. But at the same time it seeks to problematize some attempts to recast climate change as political, by emphasising the tension between articulating climate change as a struggle between heroic social movements representing humanity and fossil fuel corporations and their allies in government, and the complexity of the socio-technical systems within which fossil fuels are embedded, which thus complicate the simplifying effects of the 'end of fossil fuels' frame.
\end{abstract}

\section{Introduction}

This paper proceeds from the premise that the idea that climate change now presages the 'end of the fossil fuel age' has started to take hold in important sites of climate politics. This implication has long been the normative claim by some in climate change social movements and among some ecological economists (e.g. Flavin \& Lenssen 1990), but I suggest that it started to take hold in a more important way in the last few years.

I suggest that the 'end of fossil fuels' is a particularly interesting discursive shift in climate politics. The frame repoliticises climate change in terms of a very explicit conflict between fossil fuel interests and the rest of humanity. This is the case even when it arises out of the technocratic arena of the IPCC and the UNFCCC negotiations, and indeed the tension between the technocratic, consensus-seeking impulses of these arenas and the conflict inevitably entailed in rendering the end of fossil fuels explicit in the discourse will be interesting to see play out.

There are of course dissenters from this view (see e.g. Helm 2016). However, I am less interested here in whether the frame is 'correct', but more its rhetorical structure and implications, especially for thinking about the political economy of climate change. The analyses of whether or not the 2015 Paris Agreement's language of 'net-zero emissions' (on which more below) 'actually' means that fossil fuel production and use must end by a particular date miss the point. The interventions to argue that it was about ending fossil 
fuels aimed not a 'correct' interpretation of the PA, but rather to deploy a strategically oriented framing: to call into being the effects they claimed to describe. The 'end of fossil fuels' is more usefully understood this way - in terms of its rhetorical performativity, not its analytical rigour.

Framing matters. How we construct climate change as a problem discloses possible responses, closing down certain options and opening up others. In political economy terms, responses to climate change need to be couched in terms either of articulating a novel sort of regime of accumulation that is consistent with addressing the climate challenge (however framed), or an ability to imagine and produce a sort of post-capitalist transition to a form of society which is not predicated on endless accumulation as a fundamental logic and imperative (Newell \& Paterson 2010; Pelling et al 2011; Koch 2012). Imaginaries are integral to either of these ways of responding to capitalism's problematic relationship to climate change, and growing attention is being paid to the ways that broad politicaleconomic narratives surrounding climate change are operating to shape the activities of firms, governments and others (e.g. Levy \& Spicer 2013; Wright et al 2013; Anselm \& Hultman 2014). Successful imaginaries have a 'virtuous' quality (Paterson \& Stripple 2012; Der Derian 2001), in the sense that they effect a conflation of the ethical and the practical, rendering what can be done into what must be done. Imagining something as possible becomes a step to making it an imperative.

Imaginaries are important in general, but arguably particularly so in a situation where significant transformations are being pursued. However framed, responses to climate change entail significant disruptions, to business models, state policies, daily practices, and cultural norms, all of which mean that imagining futures is crucial to legitimising both specific projects and overall strategies to address climate change.

In what follows I first elaborate the emergence of the 'end of fossil fuels' frame within climate politics, followed by contrasting the frame with existing broad framings of climate change as a problem. The third section explores different ways that the political implications of the frame have been made, emphasising that many baulk at its full political qualities, and it should be understood to rearticulate climate change as an existential political struggle between fossil fuel interests and the rest of humanity. The fourth section then explores the tension between this sort of simplification of the politics of climate change and the complex character of the socio-technical systems within which fossil energy is embedded and which it literally fuels. It shows that most articulations of the end of fossil fuels, both in writing and in social movement strategies, focus on the extraction of coal, oil and gas from the ground, and argues that the challenge is to keep alive the radical potential of 'keep it in the ground' while working on the fossil economy as a complex system rather than something where the site of production is strategically privileged.

\section{Interpreting climate politics as 'the end of fossil fuels'}


Since around the time of the IPCC Fifth Assessment Report (AR5) in 2014, a framing of climate change politics as explicitly a question of the 'end of the fossil fuel age' has emerged. ${ }^{1}$ This novel framing (at least in how widespread it has been in public discourse ${ }^{2}$ ) seems to have come from three sources. One is in the IPCC report itself. The AR5 report (IPCC 2014) stated that for a scenario that would have a reasonable chance of limiting warming to $2^{\circ} \mathrm{C}$ (their RCP2.6 scenario), 'net emissions' would have to be zero or even negative during the $2^{\text {nd }}$ half of the $21^{\text {st }}$ century (in the figure SPM.5 (a), the date is around 2070). The report does not explicitly state that this entails eliminating fossil fuels entirely (and indeed explicitly talks about CCS as an option for getting to this target, as well as CCS with biofuels as a means to achieving negative emissions), but it does show that the zero or low carbon (i.e. excluding all fossil fuels without CCS) energy sources need to be very close to $100 \%$ of the energy mix by 2100 (figure SPM.12). However, AR5 was widely read as having the implication that fossil fuel use would have to be eliminated by the end of the $21^{\text {st }}$ century, and by implication in high-emitting countries much earlier than that. ${ }^{3}$

This framing in the IPCC report built on a series of similar arguments over previous years, using terms variously such as 'unburnable carbon', the 'carbon bubble', and 'stranded assets' (see variously Berners-Lee \& Clark 2013; Ansar et al 2013; Leaton 2014; McGlade \& Ekins 2015), with perhaps the most high-profile intervention along these lines being that of the Bank of England governor Mark Carney making the case for seeing significant amounts of fossil fuel assets being 'stranded' (Clark 2015; Fulton 2015). In the scientific field, the paper by McGlade \& Ekins (2015) in Nature was particularly influential in demonstrating quantitatively that meeting the $2^{\circ} \mathrm{C}$ target implied that no new fossil fuel exploration could be justified and existing sources would not be able to extract all the available coal, oil or gas, from their existing mines and wells, or even, especially in the case of coal, a small fraction of what remains available. This paper built on (McGlade \& Ekins 2015). None of these specifically entailed the idea that fossil fuel use had to decline to zero (although they were consistent with this claim) but they did refocus climate change

${ }^{1}$ There was also during this period a shift in focus of a number of institutions to focus on fossil fuel subsidies. In 2009, G20 leaders committed themselves to phasing out fossil fuel subsidies. The IMF on the question (IEA 2010; see also the IEA's on-going research on this at https://www.iea.org/weo/energysubsidies/, accessed 7 August 2019). The international NGO IISD has coordinated the 'global subsidies initative' involving various actors to press for eliminating fossil fuel subsidies (see Gerasimchuk et al 2017). This has helped the end of fossil fuels frame by providing additional shift in focus in climate policy towards fossil fuels per se, as opposed to 'carbon emissions'. Generally on these initiatives, see Skovgaard and van Asselt (2018). But none of these initiatives argued for the end of fossil fuel use to address climate change, merely the elimination of perverse incentives.

${ }^{2}$ Occasional mentions can of course be found in earlier works. For example, Prévot uses the term as part of his naked attempt to revitalise nuclear energy on the back of concerns about climate change (2007).

${ }^{3}$ The most recent report, the Special Report on $1.5^{\circ} \mathrm{C}$, produced in 2018 , changed this earlier conclusion in only one respect: accelerating significantly the timeframe within which the shift has to take place. 
attention on fossil fuel resources and the corporations that control them. It is also worth noting that a broader refocusing of academic attention onto the particular fossil dependence of contemporary societies, its relation to climate change, and the possibility of, in Urry's words, Societies beyond oil, also emerged during this period (see notably Mitchell 2011; Urry 2013; Huber 2013; DiMuzio 2015; Malm 2016).

The second, and perhaps most immediate site where this frame crystallised in public discourse, is the Paris Agreement (PA), agreed at the $21^{\text {st }}$ Conference of the Parties to the United Nations Framework Convention on Climate Change (UNFCCC 2015). In the runup to Paris, the influential climate change site Carbon Tracker Initiative ran a guest blog entitled 'Fossil fuels are dead - the rest is just detail' (Gilding 2015). The G7 had prefigured the PA by announcing a pledge by its members to completely phase out the use of fossil fuels by the end of the $21^{\text {st }}$ century (. The PA itself embedded the IPCC's 'net zero emissions' frame as the core goal of agreement. According to Jacobs, this translation was orchestrated by well-known climate lawyer Farhana Yamin who established a small thinktank Track 0, that mobilised in elite circles for the inclusion of the net zero goal in the PA, while coordinating with NGO organisations like Avaaz for broader public mobilisation around the goal (Jacobs 2016: 320). This 'net zero' frame is articulated in Article 4.1 of the PA, which states that:

In order to achieve the long-term temperature goal set out in Article 2, Parties aim to reach global peaking of greenhouse gas emissions as soon as possible ... and to undertake rapid reductions thereafter in accordance with best available science, so as to achieve a balance between anthropogenic emissions by sources and removals by sinks of greenhouse gases in the second half of this century ... (UNFCCC 2015: Article 4.1)

Many framed Paris as the 'beginning' of the end for fossil fuels. This is despite the fact that the PA never directly mentions fossil fuels in its text: UNFCCC texts almost never do to avoid objections by countries like Saudi Arabia. Nevertheless, CNN's headline on the PA was 'this is the end of fossil fuels' (Sutter 2015). With some variation in the nuancing of the point, this was the framing of Paris for example by Greenpeace (Naidoo 2015), the UK government's Special Representative for Climate Change Sir David King (King 2016), Al Gore and various other similar figures (Vidal and Vaughan 2015), the corporate/climate denier watch site desmog (Grandia 2015) and the network of social movements Avaaz, for example (2015). ${ }^{4}$ A good deal of this coverage reinterpreted the 'end of fossil fuels' framing of the PA onto the IPCC report, saying in effect that the PA was enacting (if imperfectly, as always) the scientific conclusion of the IPCC report. The sense that the IPCC AR5 report concluded that fossil fuels needed to be eliminated became retrospectively stronger after Paris. Piggot et al (2017) work through the logic of the PA in terms of a 'fossil fuel phase-down' most fully: detailing how individual countries could frame their Nationally Determined Contributions (the key state obligation in the PA) in terms of a phase out of fossil fuel production and consumption.

\footnotetext{
${ }^{4}$ For other examples of this sort of framing of the PA, see Burke (2015), Arens et al. (2015), or Brauers \& Richter (2016). For others who raise it as a question, even if they don't fully embrace the frame, see Donovan (2016), Jacobs (2016) or Lewis (2016).
} 
There are of course dissenters from this interpretation of the PA (e.g. Levi 2015; Helm 2016; Peters 2016; Aykut \& Castro 2017). Disagreement over whether or not the PA signals the end of fossil fuels centres either on the technical question of how much of the 'net-zero emissions' provisions in the PA can be met by Bioenergy with Carbon Capture and Storage (BECCS) or Carbon Dioxide Removal (CDR) (see e.g. Peters 2016; Aykut \& Castro 2017), or the more political judgment about how much governments will actually act to achieve net-zero emissions, and the obvious contradiction between the $1.5^{\circ} \mathrm{C}$ (or even $2^{\circ} \mathrm{C}$ ) goal and the emissions reductions that countries NDCs add up to (see e.g. Helm 2016). ${ }^{5}$ But as noted in the introduction, it more useful to see these framings of Paris in terms of their rhetorical entailments (Coward 2017: 12, citing Lakoff and Johnson 1980) than their descriptive accuracy.

These two emerge from highly institutionalised, government driven processes. But the third source of the rise of the end of fossil fuels frame is in a variety of social movements articulating more radical approaches to climate change from the mid-2000s onwards, usually centred around a narrative of 'climate justice', and culminating, in the context of this article at least, in the movement for fossil fuel divestment (FFD) that exploded from around 2012 onwards. Aykut and Castro (2017: 177-9) trace this back to campaigns against oil extraction in the global South in the 1990s, notably the Ogoni campaign against Shell in Nigeria, as well as in Ecuador, and occasional calls for a global moratorium on oil exploration. They argue this was invigorated during the late 2000s by (a) President Correa of Ecuador attempting to get money to shut off the Yasuní park from oil exploration, (b) the rise of fracking and tar sands in US and Canada and (c) the institutionalisation of $2{ }^{\circ} \mathrm{C}$ target in negotiations. Jacobs similarly suggests that after the failure of Copenhagen, mainstream environmental NGOs switched tack, campaigning less explicitly on climate change and focusing instead on stopping fossil fuel extractive activities, with considerable success, in particular in stopping the development of new coal-fired power plants (Jacobs 2016: 318). At the same time, their tactics became more confrontational, with the spread of direct action repertoires to more mainstream groups around the time of Copenhagen (Hadden 2015).

Within the climate negotiations, Aykut and Castro (2017) suggest the first calls to 'leave it in the ground' were made by NGOs at Durban at COP17 in 2011. These claims were then reinforced by the logic of the IPCC's AR5 to produce the 'unburnable carbon' storyline. The discourse of the FFD extends the 'keep it in the ground' frame, and explicitly declared 'war' on fossil fuels. Bill McKibben's two articles in Rolling Stone magazine (2012; 2013), in particular, had this declaration of war, and the associated construction of the fossil fuel industry as the 'enemy', and the closely related moralising of investment in fossil fuels (since it becomes a particular sort of evil to profit from enemy activities), at the core of their frames (Mangat et al 2018).

${ }^{5}$ This leaves out of course the way that this increasingly sharp frame also served to legitimise projects for Solar Radiation Management forms of geoengineering, which may respond to aspects of the climate crisis without addressing emissions or fossil fuels. 
Alongside these macro-frame shifts towards 'the end of fossil fuels', have been smaller, more subtle, but supportive shifts. One is the attention to fossil fuel subsidies across a range of international organisations and NGOs (see generally Skovgaard and van Asselt 2018). In 2009, G20 leaders committed themselves to phasing out fossil fuel subsidies. The IMF produced a working paper in 2015 demonstrating the scale of such subsidies and arguing for their end (Coady et al 2015; for an update see Coady et al 2019). The IEA similarly has been arguing for the end of fossil fuel subsidies and has provided input to G20 discussions on the question (IEA 2010; see also the IEA's on-going research on this at https://www.iea.org/weo/energysubsidies/, accessed 7 August 2019). The international NGO IISD has coordinated the 'global subsidies initiative' involving various actors to press for eliminating fossil fuel subsidies (see Gerasimchuk et al 2017). This has helped the end of fossil fuels frame by providing additional shift in focus in climate policy towards fossil fuels per se, as opposed to 'carbon emissions'. But none of these initiatives argued for the end of fossil fuel use to address climate change, merely the elimination of perverse incentives.

Another smaller related shift has been in more micro- forms of renaming. Some of this is to do with the frame of climate change itself. There have been similar attempts previously (going back to the late 1980s when the terms greenhouse effect, global warming and climate change were all in play, with different understandings of what each meant), with people for example suggesting 'global weirding' or various other frames. But in the last few years these seemed to have got traction, with terms like 'climate crisis' being adopted by The Guardian newspaper for example, (largely successful) campaigns for many political institutions to declare 'climate emergency', and 'climate breakdown' also becoming more popular amongst movement activists. And in relation to fossil fuels specifically, we see attempts to shift the framing of these. A key approach here is to focus on the non-fuel uses of fossil resources and thus the opportunity costs of burning them (e.g. Kroll 2013), although it should be recognised that there are a lot of process emissions involved in oil refining, as well as of course the downstream problem of increased plastics production that would be entailed.

\section{Competing frames of climate change}

The radical quality of the end of fossil fuels frame becomes particularly clear when contrasted with previous widespread framings of climate politics. Many of these either explicitly seek or implicitly assume that the pursuit of consensus is an important goal and thus in economic terms seek 'Pareto optimal' solutions. Not all engage in depoliticization: collective action frames can envisage conflict as integral to the pursuit of cooperation, and just transition frames understand climate action in the context of relations of class, gender and race which have important political dynamics. But each of these imaginaries can, I would argue, be recuperated by efforts to present climate change as a 'post-political' issue (Swyngedouw 2010, and see more below). This can be seen in the following five frames at least. These are presented in a manner that is necessarily brief manner but hopefully captures the essence of each frame. All of these frames can be understood as imaginaries in the sense recounted above: while they are presented here rather briefly to focus on the key premises and characteristics of the frame, they can nevertheless be understood as broad 
social imaginaries, embedded in particular governing institutions, professional networks, and social practices - they generate both possibilities and imperatives as alluded above.

First is the framing of climate change as a simple 'emissions problem'. Here, climate change is understood in relation to the immediate emissions $-\mathrm{CO}_{2}, \mathrm{CH}_{4}, \mathrm{CFCs}$, etc. - but the frame is that the underlying sources of those emissions are not interrogated (an 'emissions fetishism' if you like, see Lohmann 2010). At the same time, the focus is on the departure from status quo of emissions levels rather than an end goal. The structure of UNFCCC agreements and national policy processes has tended to reflect this frame, in the UNFCCC's initial goal (in articles $4.2 \mathrm{a}$ and $\mathrm{b}$ ) of stabilising industrialised countries' emissions by 2000 at 1990 levels, the Kyoto Protocol's goal of a 5.2\% cut of industrialised countries' emissions by 2008-2012, and many countries individual targets from their unilateral ones announced in the early 1990s through to their NDCs under the Paris Agreement. This focus on departure from the status quo focuses attention on the short to medium term cuts by 5,10 or $20 \%$, neglecting any sense of broad transformations involved in responding to climate change in favour of focusing on specific gains within the existing economic model.

The second is of climate change as a 'market failure' problem. This is the dominant economists' understanding of the problem, reflecting their neoclassical assumptions (see classically Stern 2007). Markets either fail to adequately reflect the 'real' costs of GHG emissions and thus intervention is needed to 'internalise' these costs (the Pigouvian approach), or alternatively there are inadequately specified property rights that lead to suboptimal resource use (the Coasian approach). Either way, intervention, either through taxation or allocating property rights is needed to correct these market failures. Intrinsically however, it is not necessary to establish a particular end goal in terms of levels of emissions; rather, once prices adequately reflect real costs, the market will decide the 'optimal' rate of GHG emissions.

Third is a related understanding of climate change as a 'global commons' problem. This is ubiquitous especially in thinking about the global dimensions of climate change as exemplified in the relevant chapter of the last IPCC report (Stavins et al 2014). Here, the problématique of climate is turned into one of cooperation: how to get disparate actors with different interests, but a shared common interest in 'solving the problem', to overcome both their specific differences and the general problem of trust and free-riding seen to be persistent in such collective action problems. As Tom Princen usefully reminds us, however, cooperation can be quite extensive and at the same time utterly useless in addressing the underlying problem (Princen 2003; 2005).

Fourth is the discourse of 'decarbonisation' (see e.g. http://deepdecarbonization.org/). This discourse, which emerged first around 2000, introduces an important shift, in that it does focus explicitly on the question of transformation of the energy system, and contains within it an explicit end goal (see Paterson 2016 on the logic of 'decarbonisation' as a frame). The discourse has certainly been productive in political terms, enabling some countries to imagine more radical policies than a narrower 'emissions problem' frame has. But decarbonisation remains quite slippery and highly malleable in that what decarbonisation 
might mean is unclear. In many of its manifestations, it has become a focus on meaning that the carbon doesn't get in the atmosphere (via CCS) or even that it does get there but is then removed (via CDR technologies). In this case it is perhaps simply a radical version of the emissions problem, enabling an imagination of zero emissions without necessarily changing the energy system that radically. But decarbonisation permits of more radical interpretations also, including that of a transition away from fossil fuels.

Finally is the 'low carbon transitions' understanding of climate change (e.g. Scrase \& Smith 2009; Bulkeley et al 2010; Geels 2014). The transitions approach has become a dominant frame especially in some Northern European countries, and also frames climate change as a question of energy system transformation. However, compared to the decarbonisation frame, it is much more specific in emphasising the transition as a sociotechnical one in the energy system (whereas decarbonisation focuses principally on the carbon itself), and focuses closely on how transitions in complex systems occur. The notion of transitions has also been used in other contexts, notably in the notion of 'just transitions' that arose in union-led social movements in North America. This form of the frame is rather different, still focused on the need to transition towards 'clean energy', but articulated explicitly in relation to social movements and especially unions as integral to the process, and avoiding environmental injustice in the way a transition is pursued (see e.g. Kinder 2017; ILO 2015; Healy \& Barry 2017).

\section{Fossil fuels ends, de- and re-politicisation}

What then are the implications, or entailments, of the 'end of fossil fuels' as a frame? A few works have attempted to think about this explicitly. What we can discern in their elaboration of its implications is a desire to avoid, or baulk at the political implications of the frame.

In some interpretations of the PA, for example, the narrative ran that even if the Agreement was inadequate to generate the end of fossil fuels, they would simply be made obsolete by collapsing renewable energy prices and technical change. 'It is now becoming clear we've reached a tipping point where fossil fuels will enter terminal decline, independently of climate policy action', wrote Paul Gilding for the Carbon Tracker Initiative (2015). For Gilding, the key shift is one from where questions of energy are basically ones of resources to ones where technology becomes the key element in energy systems, generating a situation where 'where prices keep falling, quality keeps rising, change is rapid and market disruption is normal and constant'. This generates a situation where large scale fossil fuel systems are unable to adapt to the rapid pace of change and get progressively out-competed by the combination of small-scale, ever-cheaper renewable energy systems, rapidly improving electricity storage systems, continuously improving electric vehicles (that themselves also become part of the electricity storage solution). ${ }^{6}$

Dieter Helm (2017) draws similar conclusions. Even if more ambiguous as to whether or not we are seeing the beginning of the end of fossil fuels, to the extent that we are, it is

\footnotetext{
${ }^{6}$ For others displaying this sort of logic, see Johnston (2017), or Donovan (2017).
} 
driven by the interaction of (a) what he calls the 'end of the supercycle', that is the return of persistent low energy prices driven by technical change (notably the rise of the technologies that enable fracking and tar sands extraction) and thus the low incentives for expanding fossil fuel capacity, (b) the rise of carbon constraints, which however inadequate they currently are (and he doesn't think the PA is a strong enough signal yet), are only going to get more severe over time, and (c) the rise of 'electric futures', and the combinations of advanced solar and batteries in particular which will drive first oil out of transport, and then coal and gas out of electricity.

These depoliticised understandings of the end of fossil fuels are based largely in accounts of techno-economic change. Princen, Manno and Martin (2015a) do however produce a book that is explicitly thinking about the end of fossil fuels as a political question. Their account of politics is however rather ambiguous. At one point they state that 'Our focus ... is on the politics, broadly construed where power is central, of deliberately keeping fossil fuels in the ground' (Princen et al 2015b: 27). For a good deal of the time, however, they use politics to refer to the 'influencing, shaping, organizing, negotiating, strategizing', and thus to their project as one of 'normative theorizing' (Princen et al 2015b: 25, 27), and thus in a way more akin to a colloquial use as in 'my politics is progressive', than an analytic concept. This is underscored when they distinguish three sorts of 'politics' - a 'politics of accommodation' - a strategy of global management within existing frameworks, a 'politics of total extraction', i.e. the preferred strategy of those holding fossil fuel assets, and a politics 'of urgency, of transitioning out of fossil fuels, of confronting extremely powerful actors' (Princen et al 2015b: 10).

But on the point of 'confronting extremely powerful actors', they are rather more ambivalent. They later argue that while the struggle is against fossil fuels, this is not the same as being against the fossil fuel industry: 'suffice it to say that by delegitmization [of fossil fuels], we do not mean a vilification of the fossil fuel industry' (Princen et al 2015b: 12). But this depoliticised understanding is clearest in Princen and Santana's chapter about 'exit strategies' (2015), which argue that the end of fossil fuels could arrive because of the self-interested exit strategies of fossil fuel corporations. They point out that in specific sites, companies involved in coal, oil and gas are always making decisions to 'leave it in the ground' - abandoning specific mines or wells, usually with something like $50 \%$ of the total resource still underground. Whether or not we are persuaded by this as a plausible scenario, it is nevertheless a depoliticised account of how fossil fuels may come to an end.

As in some of the academic literature surveyed above, many baulk at the political implications of the ends of fossil fuels. A useful illustration of this process can be seen in the dynamics of a divestment campaign at the University of Ottawa (where I used to work) during 2015-16.

The outcome of this campaign could be termed a 'reverse passive revolution'. At the University of Ottawa, as on many other campuses, students had organised a divestment campaign (see http://www.fossilfreeuo.org/), supported by many staff. The students produced a report and got a large number of petition signatures, submitted these to the university administration and organised a number of (fairly conventional) campaign events. 
The administration sat on these for a while, and the sense was that they were trying to wait for it to go away. Then at the beginning of 2016, the university sent an email around to the student group and various people on campus (academics with relevant expertise, the campus sustainability manager, etc.) and a couple of consultants they had used for an internal evaluation to organise a public meeting to air views and feed into a decision to be made by the Board of Governors in April 2016. The messages were decidedly mixed.

But the outcome was very interesting. In effect, the university's official decision was that it would not divest, but that instead it would produce a range of measures that continue the university's work of shifting the campus operations, including its investment portfolio, away from fossil fuels and GHG emissions. The university was already in fact very well placed to make leadership claims in this regard, with relatively low levels of GHG emissions already in place and a credible strategy for further reductions (see e.g. University of Ottawa 2015). But there in the detail was the statement that they would take their investments out of the fossil fuel interests they had remaining (the company names were stated explicitly) and shift that money into 'clean energy' investments. In other words, the university decided to divest its money while saying it had decided not to do so. ${ }^{7}$

What to make of this story? It seems to me that it is evidence of the increasing recognition by mainstream institutions like the University of Ottawa that the long-term goal is zero fossil fuels, and that it thus is sensible to take long-term investment out of fossil fuel investments. But at the same time the university baulked at the political logic of this - not wanting to be seen to take sides in the 'war on coal' (or oil and gas in the Canadian case, coal being almost already eliminated from the fuel mix). They deployed the more technocratic 'stranded assets' storyline, as well as a more feelgood 'playing a part in the energy sources of the future' sort of rationale, for their investment switching.

This instance represents thus an interesting dynamic has often occurred where there is a plea by university managers, fund managers and the like, for more 'constructive engagement' with fossil fuel industries to shape their 'responsible' development. This depoliticising strategy, central to approaches for CSR, ethical investment, and the like for the last 20-30 years, has been premised on the idea that the goal is to transform existing businesses and make them 'more sustainable' (or more in line with human rights or fair trade norms). But it falters rather when the goal explicitly becomes no longer reducing harm but eliminating an entire sector. There can be no accommodation with an industry that needs to cease to exist, and the strategic goal becomes much more clearly finding ways of circumventing the entrenched social power of that industry.

Ironically, then this instance of attempts to depoliticise the question of divestment, ends up underscoring how political the end of fossil fuels frame is. Compared to the other frames

\footnotetext{
${ }^{7}$ For the details of these decisions and competing interpretations, see variously University of Ottawa Treasury and Finance Committee (2016), University of Ottawa (2016a, b), University of Ottawa Executive Committee of the Board of Governors (2016), Fossil Free uOttawa (2016), Crawford (2016), Kotyk (2016).
} 
sketched in the previous section, the 'end of fossil fuels' frame is much more strident, confrontational, and definite in where it sees the response to climate change ending up. It is hard to see how it is as easily co-opted politically as decarbonisation can be, and focuses attention squarely on the challenge of a fundamental transformation in the sources of energy for the global economy. What then do I mean by thinking about it as a politicising move?

Despite the attempt by Princen and colleagues to 'love the sinner, hate the sin', thinking about climate change as the end of fossil fuels entails thinking about it as a fundamental conflict between competing interests, visions, and values, and the power relations that are both sustained by and sustain those competing interests, visions, and values. In other words, it articulates climate change explicitly as an agonistic politics (Machin 2013), as opposed to a technocratic, narrowly economic, or even deliberative one. It could be understood via Gramscian accounts of hegemony and counter-hegemony, and thus as a process of contestation and cooptation. But the rhetorical form of 'the end of ...' makes cooptation relatively difficult to imagine, as suggested above. Rather the contestation takes on a more Manichean form, with the total victory of one side or the other the only possible outcome. The discourse of divestment movements frequently makes this explicit: the enemy is evil and must be defeated, no compromise can be countenanced (Mangat et al 2018). In McKibben's terms:

A rapid, transformative change would require building a movement, and movements require enemies. As John F. Kennedy put it, 'The civil rights movement should thank God for Bull Connor. He's helped it as much as Abraham Lincoln.' And enemies are what climate change has lacked. But what all these climate numbers make painfully, usefully clear is that the planet does indeed have an enemy ... we need to view the fossil-fuel industry in a new light. It has become a rogue industry, reckless like no other force on Earth. It is Public Enemy Number One to the survival of our planetary civilization (McKibben 2012, as quoted in Mangat et al 2018: 205).

\section{Repoliticisation, 'heroic agency' and the complexity of transitions}

The way however that the frame repoliticises climate change however contains interesting tensions. Specifically, while climate change may require 'enemies' to be identified in order to sharpen the focus of a struggle and provide powerful affective motivations for political action, nevertheless the embedding of fossil fuels in the global economy and daily life - in its cultural political economy (Paterson 2007) if you like, is considerably more complex than that of a single industry that can be opposed through direct political confrontation at identifiable sites.

It is a discourse with particular political economy assumptions embedded in it and implications for the trajectory of the global economy. It makes the political dynamics of energy systems much more explicit. In the FFD movement's discourse, the embedded social power of energy industries is explicit as is the need to challenge it directly (Mangat et al 2018; Healy \& Barry 2017). There is a recognition thus that the power of fossil fuel 
corporations is embedded in the technological infrastructure that enables its expansion and continued operation, as well as in the broad financialised embedding in a wide range of social institutions via pensions, life insurance, savings, and endowments. But despite this implication, the focus of attention is drawn to specific sites, usually thoe of fossil fuel production.

The choices made in empirical chapters of Princen et al's Ending the Fossil Fuel Era are instructive here. Despite the injunction to avoid blaming the fossil fuel industry, all of the chapters are focused on sites of extraction of fossil fuels - coal mines, oil reserves, notably - and social movement campaigns against them. That is to say, articulating the 'end of fossil fuels' engenders a sort of simplification in the political focus to the sites of fossil fuel extraction (and perhaps distribution, as in pipeline politics), and therefore to the agents the corporations - doing that extraction. In principle, it would be possible to imagine chapters in a book on 'ending the fossil fuel era' that had other foci, for example on the politics of shifting cars from internal combustion engines to electricity, but this is not the effect the frame has in what it makes us focus on. Indeed Princen et al are explicit in their opening frame, the problem is 'extraction, not emissions; fossil fuels, not carbon' (Princen et al 2015b: 5).

Berners-Lee and Clark (2013) make this argument very explicitly. They argue that attempts to regulate the consumption of fossil fuels have failed, and will always be subject to collective action failures where even if some governments succeed in regulating fossil fuels adequately, others will free ride on those efforts. They also argue that rebound effects for local attempts to reduce fossil fuel consumption are extensive. As a consequence, any fossil fuels that are brought out of the ground will find a market somewhere and be consumed somewhere in the world: that initial moment of extraction is therefore where to focus effort.

The strategies of movements associated with the frame involve a similar simplifying move to a focus on specific sites, and with the exception of divestment which focuses on finance and investment, on specific sites of production of fossil fuels - to opposition to pipeline development, and direct action to prevent fracking in various places. The shift in discourse is allied to a shift in action focused on the physical prevention of the extraction of fossil fuels or their move to market, in one instance proposing that as a form for a global climate treaty (Newell \& Simms 2019). ${ }^{8}$

The frame thus provides an interesting contrast to the now commonplace understanding of climate change as a problem of complexity (Hoffmann 2011; Levin et al 2012). Indeed, critics of divestment movements at deploy this narrative often charge them with hypocrisy since they continue to drive and use fossil fuels in other ways (Gunster et al 2018). The

\footnotetext{
${ }^{8}$ This is perhaps why we see figures like Mark Jaccard, previously well-known for a book that stirred controversy because of the title (and argument) of Sustainable Fossil Fuels (Jaccard 2005) being closely involved in campaigns against oil and gas pipelines in British Columbia. Even if he holds the view that some fossil fuel use can be made sustainable (via CCS, notably), expanding fossil fuel infrastructure remains definitively something to be resisted.
} 
hypocrisy charge here involves a double move: the charge depends rhetorically on a notion of the sovereign individual who must be ethically consistent to be politically credible, thus abstracting from the complexity of fossil fuel use and its socio-technical embeddedness. If you are going to argue for divestment, you must yourself be using no fossil fuels. But the charge is intelligible only because of an implicit recognition of this complexity: no one would need to be a climate hypocrite if they actually controlled the decisions around urban infrastructure, electricity systems, food production, and so on. The end of fossil fuels frame itself perhaps entails a similar double move. The rhetoric entails the radical simplification of climate change into an us vs. them politics even while those articulating it routinely recognise the complexity of the energy system, that one single site of action (investment, consumption, infrastructure, etc.) is thus insufficient, and that individuals are themselves bound up with fossil fuel use in ways that complicate the 'FF industry as enemy' narrative.

Comparisons to the decarbonisation frame are perhaps also instructive. Decarbonisation has arguably favoured a creative, experimental, positive political economy focused on socio-technical innovation and imagination. It draws our attentions to the novel forms of policy, technology, social practice and business opportunities entailed in responding to climate change, in ways that can be understood readily as the pursuit of a decarbonising regime of accumulation. It has been useful in informing a range of policy interventions on climate change, in for example in the UK, where it has informed the Blair government's approach culminating in the Climate Change Act of 2008, and in Germany where it has informed the Energiewende, as well as various interventions by non-state actors. The end of fossil fuels by contrast is much more stark in its message, focusing on what must be stopped rather than what needs to be created. While politically this might open up space for more radical action, it is not clear how these two - the rhetorical simplicity and attractiveness of the 'end of ...' frame, and the complexity of transforming energy systems and the global economy, can be made to articulate with each other.

The question then is how to keep alive the sort of political imaginary involved in the end of fossil fuels frame, and the way it sharpens our focus on the ends of climate action, while recognising that enacting such ends are unlikely to be brought about solely by specific forms of political action to oppose pipelines, fossil fuel investments or coal mines, but rather by multiple forms of action in, for example, urban planning, fiscal policy, electricity market regulation, infrastructure building, and so on. A just transitions frame may be useful here as it enables the focus on fossil fuel companies to be maintained while recognising the nuance of how various actors (workers, notably) in the 'fossil fuel bloc' may not all have the same interests. Each of these sites has their own political dynamics which would need to be articulated with the notion of the end of fossil fuels in specific ways, and where it is not always clear how the conflicts and different power relations in specific sites are helped by a broad frame like the end of fossil fuels.

These tensions are also useful for thinking about the limits of current attempts to think about climate change either in terms of 'agonistic politics' (Machin 2013) or 'post-politics' (Anselm \& Hultman 2014; MacGregor 2014; Swyngedouw 2010; Rice 2016). These related arguments about the politics of climate change both tend to abstract the political struggle over climate change from the complex sociomaterialities of getting rid of fossil 
fuels, or of what Bulkeley (2015) calls the 'accomplishing' of climate governance. Or as White puts it, in the context of just transitions, 'post-carbon futures are not simply going to emerge through protest and policy shifts alone. Just transitions will have to be imagined and built, fabricated and realized, coded and created' (2019: 1). Indeed those arguing for a 'post-political' reading of climate change tend perhaps to regard such attention to the details variously of carbon accounting (Lovell \& Mackenzie 2011; Thistlethwaite 2011; Lövbrand \& Stripple 2011), low carbon buildings (Lovell 2016; Karvonen 2016; Quitzau \& Hoffmann 2016) or the microdynamics of corporate low carbon initiatives in for example, orange juice (Mylan 2016a), or low temperature washing (Mylan 2016b), as in important ways complicit in the reproduction of a 'post-political' account of climate change. Instead however, these areas of research (and many others that I could have chosen here) could be understood as multiple sites at which political contestation occurs (of course circumscribed by the particular institutional, technical and historical contexts they occur in). In the terms set out by Craig in the opening to this special section, then, they entail recognising that the form of agency that might open up political space for new forms of intervention aimed at more radical transformations may not be the same forms of agency as those needed to effect the 'accomplishing' of those transformations.

\section{References}

Ansar A., Caldecott, B. and Tilbury, J. (2013) Stranded assets and the fossil fuel divestment campaign: what does divestment mean for the valuation of fossil fuel assets? Stranded Assets Programme, October, London, UK: University of Oxford's Smith School of Enterprise and the Environment, available at: http://www.fossilfuelsreview.ed.ac.uk/resources/Evidence $\% 20-\% 20$ Investment, $\%$ 20Financial,\%20Behavioural/Smith\%20School\%20-\%20Stranded\%20Assets.pdf (accessed 2 November 2017).

Anshelm, J. and Hultman, M. (2014), Discourses of Global Climate Change: Apocalyptic Framing and Political Antagonisms (London: Routledge).

Arens, C., Hermwille, L., Kreibrich, N., et al. (2015), The Paris Agreement: Kick-Offfor True Global Climate Cooperation (Wuppertal: Wuppertal Institute for Climate, Environment and Energy), available at: https://wupperinst.org/uploads/tx_wupperinst/Paris_short_assessment.pdf (accessed 17 October 2017).

Avaaz (n.d.), 'Victory! The end of fossil fuels has begun ...', available at: https://secure.avaaz.org/en/climate story loc/ (accessed 30 October 2017).

Aykut, S.C. and Castro, M. (2017), 'The end of fossil fuels? Understanding the partial climatisation of global energy debates', in S.C. Aykut, J. Foyer, and E. Morena (eds), Globalising the Climate: COP21 and the Climatisation of Global Debates (London: Routledge), pp. 173-193.

Berners-Lee, M. and Clark, D. (2013), The Burning Question: We Can't Burn Half the World's Oil, Coal and Gas. So How Do We Quit? (London: Profile Books Ltd).

Brauers, H. and Richter, P.M. (2016), The Paris Climate Agreement: Is it sufficient to limit climate change? 91, Research Report. DIW Roundup: Politik im Fokus, available at: https://www.econstor.eu/handle/10419/127574 (accessed 6 October 2017).

Bulkeley, H. (2016), Accomplishing Climate Governance (Cambridge: Cambridge University Press). 
Bulkeley, H., Broto, V.C., Hodson, M., et al. (2010), Cities and Low Carbon Transitions (London: Routledge).

Burke, T. (n.d.), 'What Paris means for fossil fuels', available at: http://tomburke.co.uk/2015/12/17/paris-and-the-future-of-fossil-fuels/ (accessed 30 October 2017).

Clark, P. (2015), 'Mark Carney warns investors face 'huge' climate change losses', Financial Times, 29 September, available at: https://www.ft.com/content/622de3da-66e6-11e5-97d0-1456a776a4f5 (accessed 2 November 2017).

Coady, D., Parry, I., Sears, L., and Shang, B. (2015), How Large are Global Energy Subsidies. IMF Working Paper 15/105 (Washington DC: IMF).

Coady, D., Parry, I., Le, N.-P., and Shang, B. (2019), Global Fossil Fuel Subsidies Remain Large: An Update Based on Country-Level Estimates (Washington DC: IMF).

Connolly, K. (2015), 'G7 Leaders Agree to Phase out Fossil Fuel Use by End of Century'. The Guardian, 8 June, available at: http://www.theguardian.com/world/2015/jun/08/g7-leaders-agree-phase-outfossil-fuel-use-end-of-century, accessed 7 August 2019.

Coward, M. (2017), 'Against network thinking: A critique of pathological sovereignty', European Journal of International Relations, 24 (2), pp. 440-463.

Crawford, B. (2016), 'uOttawa to seek ways to 'shift' fossil fuel investments; rejects full divestment', Ottawa Citizen, 27 April, available at: http://ottawacitizen.com/news/local-news/uottawa-commits-to-cutting-carbonfootprint-but-not-full-divestment-from-fossil-fuels (accessed 2 November 2017).

Der Derian, J. and Vallely, J. (2001), Virtuous War: Mapping the Military - IndustrialMedia-Entertainment Network (Boulder, Colo: Westview Press Inc).

DiMuzio, T. (2015), Carbon Capitalism: Energy, Social Reproduction and World Order (Lanham MD: Rowman \& Littlefield International).

Donovan, C. (2017), 'Is this the end of fossil fuels?', Imperial College Business School blog, available at: https://www.imperial.ac.uk/businessschool/knowledge/management/end-fossil-fuels/ (accessed 17 October 2017).

Flavin, C. and Lenssen, N. (1990), 'Beyond the petroleum age: Designing a solar economy', Ekistics, 57 (344/345), pp. 342-361.

Fossil Free uOttawa (2016), 'Yes, the University of Ottawa has committed to divestment. They just don't know it yet', available at: http://www.fossilfreeuo.org/ (accessed 2 November 2017).

Fulton, D. (2015), 'Bank of England Issues Warning Over Looming 'Carbon Bubble' Threat', available at: http://www.commondreams.org/news/2015/03/03/bankengland-issues-warning-over-looming-carbon-bubble-threat (accessed 27 February 2016).

Geels, F.W. (2014), 'Regime Resistance against Low-Carbon Transitions: Introducing Politics and Power into the Multi-Level Perspective', Theory, Culture \& Society, 31 (5), pp. 21-40.

Gerasimchuk, I., Wooders, P., Merrill, L., Sanchez, L., and Kitson, L. (2017), A Guidebook to Reviews of Fossil Fuel Subsidies (Winnipeg: IISD). 
Gilding, P. (n.d.), 'Fossil fuels are dead - the rest is just detail', available at: https://www.carbontracker.org/fossil-fuels-are-dead-the-rest-is-just-detail/ (accessed 17 October 2017).

Grandia, K. (n.d.), 'Agreement in Paris Paves Road For The End of Fossil Fuels', available at: https://www.desmogblog.com/2015/12/12/paris-agreement-paves-road-endfossil-fuels (accessed 30 October 2017).

Gunster, S., Fleet, D., Paterson, M., et al. (2018), “Why Don't You Act Like You Believe It?": Competing Visions of Climate Hypocrisy', Frontiers in Communication, 3. DOI: $10.3389 /$ fcomm.2018.00049.

Hadden J. (2015), Networks in Contention (Cambridge: Cambridge University Press).

Healy, N. and Barry, J. (2017), 'Politicizing energy justice and energy system transitions: Fossil fuel divestment and a "just transition"”, Energy Policy, 108, pp. 451-459.

Helm, D. (2016), 'The future of fossil fuels - is it the end?', Oxford Review of Economic Policy, 32 (2), pp. 191-205.

Helm, D. (2017), Burn Out: The Endgame for Fossil Fuels (New Haven, CT: Yale University Press).

Hoffmann, M.J. (2011), Climate Governance at the Crossroads: Experimenting with a Global Response after Kyoto (Oxford: Oxford University Press).

Huber, M. (2013), Lifeblood (Minneapolis: University of Minnesota Press).

IEA (2010), The Scope of Fossil-Fuel Subsidies in 2009 and a Roadmap for Phasing out Fossil-Fuel Subsidies, An IEA, OECD and World Bank Joint Report Prepared for the G-20 Summit (Paris: IEA).

ILO (2015), Guidelines for a just transition towards environmentally sustainable economies and societies for all (Geneva: International Labour Organization, available at: $\quad$ http://www.ilo.org/wcmsp5/groups/public/---ed emp/--emp ent/documents/publication/wcms 432859.pdf

IPCC (2014), 'Summary for Policymakers', in Climate Change 2014: Synthesis Report (Geneva: Intergovernmental Panel on Climate Change).

Jaccard, M. (2005), Sustainable Fossil Fuels (Cambridge: Cambridge University Press).

Jacobs, M. (2016), 'High pressure for low emissions: How civil society created the Paris climate agreement', Juncture, 22 (4), pp. 314-323.

Johnston, I. (2017), 'Plunging price of renewable energy makes end of fossil fuels inevitable, says report', Independent, 30 March, available at: http://www.independent.co.uk/environment/renewable-energy-transition-fromfossil-fuels-inevitable-canada-clean-energy-a7658891.html (accessed 30 October 2017).

Karvonen, A. (2016), 'Low-Carbon Devices and Desires in Community Housing Retrofit', in H. Bulkeley, M. Paterson, and J. Stripple (eds), Towards a Cultural Politics of Climate Change (Cambridge: Cambridge University Press), pp. 51-65.

Kinder, J. (2017), 'The Coming Transition: Fossil Capital and Our Energy Future', Socialism and Democracy, 30 (2), pp. 8-27.

King, D. (2016), 'Biggest opportunity of our age', Science 351 (6269), pp. 107-107.

Koch, M. (2012), Capitalism and Climate Change: Theoretical Discussion, Historical Development and Policy Responses (London: Palgrave).

Kotyk, A. (2016), 'University of Ottawa becomes first Canadian university to divest from fossil fuels', available at: http://rabble.ca/news/2016/04/university-ottawa- 
becomes-first-canadian-university-to-divest-fossil-fuels (accessed 2 November 2017).

Kroll, M. (2013), The Monetary Cost of the Non-Use of Renewable Energies. World Future Council, available at: https://www.worldfuturecouncil.org/monetary-cost-non-userenewable-energies/, accessed 7 August 2019.

Lakoff, G. and Johnson, M. (1980), 'Conceptual Metaphor in Everyday Language', The Journal of Philosophy, 77 (8), pp. 453-486.

Leaton, J. (2014), Unburnable Carbon - Are the world's financial markets carrying a carbon bubble? (London: Carbon Tracker Initiative), available at: https://www.carbontracker.org/wp-content/uploads/2014/09/Unburnable-CarbonFull-rev2-1.pdf (accessed 2 November 2017).

Levi, M. (2015), 'Two Cheers for the Paris Agreement on Climate Change', Council on Foreign Relations blog, available at: https://www.cfr.org/blog/two-cheers-parisagreement-climate-change (accessed 17 October 2017).

Levin, K., Cashore, B., Bernstein, S., et al. (2012), 'Overcoming the tragedy of super wicked problems: constraining our future selves to ameliorate global climate change', Policy Sciences, 45 (2), pp. 123-152.

Levy, D.L. and Spicer, A. (2013), 'Contested imaginaries and the cultural political economy of climate change', Organization, 20 (5), pp. 659-678.

Lewis, S.L. (2016), 'The Paris Agreement has solved a troubling problem', Nature News, 532 (7599), pp. 283.

Lohmann, L. (2010), 'Commodity Fetishism in Climate Science and Policy', Imperial College London, 2010.

Lövbrand, E. and Stripple, J. (2011), 'Making climate change governable: accounting for carbon as sinks, credits and personal budgets', Critical Policy Studies, 5 (2), pp. $187-200$.

Lovell, H. (2016), 'The Making of a Zero-Carbon Home', in H. Bulkeley, M. Paterson, and J. Stripple, Towards a Cultural Politics of Climate Change (Cambridge: Cambridge University Press), pp. 160-172.

Lovell H. and MacKenzie D. (2011), 'Accounting for Carbon: The Role of Accounting Professional Organisations in Governing Climate Change', Antipode, 43 (3), pp. 704-730.

MacGregor, S. (2014), 'Only Resist: Feminist Ecological Citizenship and the Post-politics of Climate Change', Hypatia, 29 (3), pp. 617-633.

Machin, A. (2013), Negotiating Climate Change: Radical Democracy and the Illusion of Consensus (London: Zed Books).

Malm, A. (2015), Fossil Capital: The Rise of Steam-Power and the Roots of Global Warming (London: Verso Books).

Mangat, R., Dalby, S. and Paterson, M. (2018), 'Divestment discourse: war, justice, morality and money', Environmental Politics, 27 (2), pp. 187-208.

McGlade, C. and Ekins, P. (2015), 'The geographical distribution of fossil fuels unused when limiting global warming to $2^{\circ} \mathrm{C}$ ', Nature, 517 (7533), pp. 187-190.

McKibben, B. (2012), 'Global Warming's Terrifying New Math', available at: http://www.rollingstone.com/politics/news/global-warmings-terrifying-new-math$\underline{20120719}$ (accessed 29 September 2015). 
McKibben, B. (2013), 'The Case for Fossil-Fuel Divestment', available at: http://www.rollingstone.com/politics/news/the-case-for-fossil-fuel-divestment20130222 (accessed 2 October 2015).

Mitchell, T. (2013), Carbon Democracy: Political Power in the Age of Oil (London: Verso). Mylan, J. (2017), "The Business of "Behaviour Change": Analysing the ConsumerOriented Corporate Sustainability Journey of Low-Temperature Laundry', Organization \& Environment, 30 (4), pp. 283-303..

Naidoo, K. (n.d.), 'COP21: shows the end of fossil fuels is near, we must speed its coming', available

at: http://www.greenpeace.org/international/en/news/Blogs/makingwaves/cop21climate-talks-paris-negotiations-conclusion/blog/55092/ (accessed 30 October 2017).

Newell, P. and Paterson, M. (2010), Climate Capitalism: Global Warming and the Transformation of the Global Economy (Cambridge: Cambridge University Press).

Newell, P. and Simms, A. (2019), 'Towards a fossil fuel non-proliferation treaty', Climate Policy. DOI: 10.1080/14693062.2019.1636759.

Paterson, M. (2007), Automobile Politics: Ecology and Cultural Political Economy (Cambridge: Cambridge University Press).

Paterson, M. (2016), 'The sociological imagination of climate futures', in P. Wapner and H. Elver (eds), Reimagining Climate Change (London: Routledge), pp. 14-28.

Paterson, M. and Stripple, J. (2012), 'Virtuous carbon', Environmental Politics, 21 (4), pp. 563-582.

Pelling, M., Manuel-Navarrette, D. and Redclift, M. (eds), (2011), Climate Change and the Crisis of Capitalism: A Chance to Reclaim, Self, Society and Nature (London: Routledge).

Peters, G.P. (2016), 'The 'best available science' to inform $1.5^{\circ} \mathrm{C}$ policy choices', Nature Climate Change, 6 (7), pp. 646-649.

Piggot, G., Erickson, P., Lazarus, M., and van Asselt, H. (2017), Addressing fossil fuel production under the Paris Agreement (Seattle: Stockholm Environment Institute).

Prévot, H. (2007), Trop de Pétrole! Energie Fossile et Réchauffement Climatique (Paris: Seuil).

Princen, T. (2003), 'Principles for Sustainability: From Cooperation and Efficiency to Sufficiency', Global Environmental Politics, 3 (1), pp. 33-50.

Princen, T. (2005), The Logic of Sufficiency. MIT Press.

Princen, T. and Santana, A. (2015), 'Exit Strategies', in T. Princen, J. Manno, and P.L. Martin (eds), Ending the Fossil Fuel Era (Cambridge, MA: MIT Press), pp. 311332.

Princen, T., Manno, J. and Martin, P.L. (2015a), Ending the Fossil Fuel Era (Cambridge, MA: MIT Press).

Princen, T., Manno, J. and Martin, P.L. (2015b), 'The Problem', in T. Princen, J. Manno, and P.L. Martin (eds), Ending the Fossil Fuel Era (Cambridge, MA: MIT Press), pp. 3-36.

Quitzau, M.-B. and Hoffmann, B. (2016), 'Strategic Engagement with Resistance against Energy-Efficient Devices: Exploring the Hidden Politics of Comfort Desires', in H. Bulkeley, M. Paterson, and J. Stripple (eds), Towards a Cultural Politics of Climate Change (Cambridge: Cambridge University Press), pp. 127-141. 
Rice, J.L. (2016), “The Everyday Choices we make Matter”: Urban Climate Politics and the Postpolitics of responsibility and action', in H. Bulkeley, M. Paterson, and J. Stripple (eds), Towards a Cultural Politics of Climate Change: Devices, Desires and Dissent (Cambridge: Cambridge University Press), pp. 110-126.

Scrase, I. and Smith, A. (2009), 'The (non-)politics of managing low carbon sociotechnical transitions', Environmental Politics, 18 (5), pp. 707-726.

Skovgaard, J. and Van Asselt, H. (2018), The Politics of Fossil Fuel Subsidies and Their Reform (Cambridge: Cambridge University Press).

Stavins, R., Conte Grand, M., den Elzen, M., et al. (2014), 'International Cooperation: Agreements and Instruments', in O. Edenhofer (ed.), Climate Change 2014: Mitigation of Climate Change. Contribution of Working Group III to the Fifth Assessment Report of the Intergovernmental Panel on Climate Change. Geneva: Intergovernmental Panel on Climate Change, available at: http://mitigation2014.org/ (accessed 9 July 2015).

Stern, N. (2007), The Economics of Climate Change: The Stern Review (Cambridge: Cambridge University Press).

Sutter, J. (n.d.), 'COP21: Paris climate change deal is end of fossil fuels', available at: http://www.cnn.com/2015/12/12/opinions/sutter-cop21-climatereaction/index.html (accessed 17 October 2017).

Swyngedouw, E. (2010), 'Apocalypse Forever? Post-political Populism and the Spectre of Climate Change', Theory, Culture \& Society, 27 (2-3), pp. 213-232.

Thistlethwaite, J. (2011), 'Counting the Environment: The Environmental Implications of International Accounting Standards', Global Environmental Politics, 11 (2), pp. 75-97.

UNFCCC (2015), Paris Agreement. United Nations, available at: http://unfccc.int/files/essential_background/convention/application/pdf/english_pa ris agreement.pdf.

University of Ottawa (2015), Report on Sustainable Development at the University of Ottawa. Ottawa: University of Ottawa, available at: http://sustainable.uottawa.ca/sites/sustainable.uottawa.ca/files/rapport_developpe ment durable_2015 en final_accessible_0.pdf (accessed 2 November 2017).

University of Ottawa (2016a), uOttawa's climate commitment helps create greener economy, available at: http://www.uottawa.ca/administration-andgovernance/board-of-governors/addressing-global-warming $\quad$ (accessed 2 November 2017).

University of Ottawa (2016b), uOttawa's climate commitment helps create greener economy for Canada, available at: http://media.uottawa.ca/news/uOttawa-climatecommitment (accessed 2 November 2017).

University of Ottawa Executive Committee of the Board of Governors (2016), Response by the Executive Committee of the Board of Governors to the Report of the Finance and Treasury Committee: Addressing Global Warming, available at: http://www.uottawa.ca/administration-and-governance/response-executivecommittee-report-finance-and-treasury-committee (accessed 2 November 2017).

University of Ottawa Finance and Treasure Committee (2016), Addressing Global Warming: The uOttawa Response. A Report from the Finance and Treasury Committee to the Board of Governors of the University of Ottawa. April, available 
at:

https://www.uottawa.ca/administration-and-

governance/sites/www.uottawa.ca.administration-and-

governance/files/report of the finance and treasury committee to the board.p df (accessed 2 November 2017).

Urry, J. (2013), Societies beyond Oil (London: Zed Books).

Vidal, J. and Vaughan, A. (2015), 'Paris climate agreement "may signal end of fossil fuel era", The Observer, 13 December, available at: http://www.theguardian.com/environment/2015/dec/13/paris-climate-agreementsignal-end-of-fossil-fuel-era (accessed 30 October 2017).

White, D. (2019), 'Just Transitions/Design for Transitions: Preliminary Notes on a Design Politics for a Green New Deal', Capitalism Nature Socialism, DOI: 10.1080/10455752.2019.1583762.

Wright, C., Nyberg, D., Cock, C.D., et al. (2013), 'Future imaginings: organizing in response to climate change', Organization, 20 (5), pp. 647-658. 